University of Nebraska - Lincoln

DigitalCommons@University of Nebraska - Lincoln

Nebraska Game and Parks Commission -- Staff

Research Publications

Nebraska Game and Parks Commission

January 1972

\title{
Ecological Significance of Vegetation to Northern Pike, Esox lucius, Spawning
}

D. B. McCarraher

Nebraska Game and Parks Commission

Robert E. Thomas

Nebraska Game and Parks Commission

Follow this and additional works at: https://digitalcommons.unl.edu/nebgamestaff

Part of the Environmental Sciences Commons

McCarraher, D. B. and Thomas, Robert E., "Ecological Significance of Vegetation to Northern Pike, Esox lucius, Spawning" (1972). Nebraska Game and Parks Commission -- Staff Research Publications. 9. https://digitalcommons.unl.edu/nebgamestaff/9

This Article is brought to you for free and open access by the Nebraska Game and Parks Commission at DigitalCommons@University of Nebraska - Lincoln. It has been accepted for inclusion in Nebraska Game and Parks Commission -- Staff Research Publications by an authorized administrator of DigitalCommons@University of Nebraska - Lincoln. 


\section{Ecological Significance of Vegeta- tion to Northern Pike, Esox lucius, Spawning}

Since 1955 , information has been collected from six Nebraska sandhill lakes to evaluate northern pike spawning success based on type of aquatic vegetation preferred by pike for spawning. The lakes, all located in Cherry County, were Big Alkali, Watts, Hackberry, Cottonwood, Shell, and Pelican. Several investigators have commented that pike year class strength is closely related to type and abundance of aquatic vegetation present in a lake (Clark and Steinbach, 1959; Forney, 1967). Documented information on spawning habitats is scant other than vague references to pike spawning over submerged vegetation or inundated meadows.

Fabricius and Gustafson (1958) apparently felt that the type of vegetation that forms the spawning mat was of small importance. They found the optimal spawning substrate for pike was a dense mat of short vegetation.

Frost and Kipling (1967) reported spawning grounds to have silty substrates with some stones and found eggs on vegetation consisting mainly of Elodea, Myriophyllum, and Nitella. They also reported that for the first few days, alevins were attached to vegetation.

Clark and Steinbach (1959) suggest that the presence of Myriophyllum sp. in a sand-spit pond adjacent to Lake Erie might be instrumental in providing natural spawning habitat for pike.

A comparison with pike eggs' density on plots of winter wheat and adjacent natural vegetation in New York showed egg deposit variation between undisturbed natural vegetation and seeded plots of winter wheat. Natural vegetation consisting of sedges, Carex sp., grasses, Spartina sp. and water plantain, Alisma sp. appeared as attractive as winter wheat as a substrate for egg disposition (Forney, 1967).

Observations by Schryer (personal communication) on pike spawning in a newly impounded reservoir in Kansas where terrestrial vegetation, including alfalfa, milo, numerous species of annual weeds, buffalo grass and blué grama, was newly inundated revealed pike eggs only in buffalo and blue grama 
TABLE 1.-Northern pike egg collections from sandhill lakes and hatchery ponds as related to vegetation, $1955-69$

\begin{tabular}{|c|c|c|c|c|c|c|c|c|c|}
\hline \multirow[b]{2}{*}{ Site type } & \multirow{2}{*}{$\begin{array}{l}\text { Number of } \\
\text { samples }\end{array}$} & \multicolumn{7}{|c|}{ Average number of eggs per $30 \mathrm{~cm}^{2}$ sample } & \multirow[b]{2}{*}{$51-100$} \\
\hline & & $\overline{0-5}$ & $6-10$ & $11-15$ & $16-20$ & $21-25$ & $26-30$ & $31-50$ & \\
\hline \multirow{5}{*}{$\begin{array}{l}\text { Flooded meadow (native } \\
\text { grasses) } \\
\text { Floded mowed hay } \\
\text { Eloded-Utricularia } \\
\text { Potamogeton-Chara } \\
\text { Mud-dead vegetation } \\
\text { Najas flexilis } \\
\text { Sand-Scirpus sp. } \\
\text { Sand-detritus } \\
\text { Scirpus-Phragmites } \\
\text { Myriophyllum- } \\
\text { Ceratophyllum }\end{array}$} & & & \multirow{5}{*}{$\underset{\mathbf{X}}{\mathbf{X}}$} & & & & \multirow{5}{*}{$\mathrm{x}$} & \multirow{5}{*}{$\mathbf{x}$} & \multirow{5}{*}{$\underset{\mathbf{X}}{\mathbf{X}}$} \\
\hline & $\begin{array}{r}10 \\
9 \\
12\end{array}$ & & & & & & & & \\
\hline & $\begin{array}{r}36 \\
8\end{array}$ & & & & & & & & \\
\hline & $\begin{array}{r}32 \\
14 \\
6 \\
8\end{array}$ & $\begin{array}{l}\underset{X}{X} \\
\text { X }\end{array}$ & & & & & & & \\
\hline & 14 & $\mathrm{x}$ & & & & & & & \\
\hline
\end{tabular}

1 Valentine Fish Hatchery Ponds (flooded mowed hay mats placed in rearing ponds as spawning aids).

grasses, indicating a preference for plants with a large amount of basal coverage.

At Lake George, Minnesota, Franklin and Smith (1963) observed that pike spawning never occurred in cattail areas, but all other vegetation types were utilized. They found the highest egg densities in mats of sterile culms of Eleocharis sp., and concluded that grasses, sedges or rushes with fine leaves appear to make the best substrates for egg disposition.

Kennedy $(1965)^{1}$ showed that spawning occurred in Irish lakes within depths of 38-76 $\mathrm{cm}$ over bottom habitat consisting of broken clumps of Phragmites sp. and on Agrostis stolonifera, Juncus bulbosus, Mentha sp., Hip. puris sp., and Fontinalis sp.

Marsh grass, Calamagrostis canadensis, was listed by Carbine (1941) as the dominant plant in the drainage ditches flowing into Houghton Lake. Most of the pike spawning took place in these ditches.

The intent of this note is to reveal pike selectivity preferences for specific aquatic floristic associations in the sandhill region of $\mathrm{Ne}$ braska.

\section{STUDY SITES}

A total of $155(30 \times 30 \mathrm{~cm})$ sites were sampled from six natural lakes and three hatchery ponds. Lakes and ponds ranged in size from 3 to 410 ha and varied in water quality characteristics from fresh $(<200 \mathrm{mg} / 1$ alkalinity) to slightly alkaline $(200-900 \mathrm{mg} / \mathrm{l}$ alkalinity) . The lakes contained standing crops of pike of about $30-65 \mathrm{~kg} / \mathrm{ha}$. Forage species, i.e., blue-

\footnotetext{
${ }^{1}$ Spawning of pike in four Irish lakes in 1965. Unpublished M.S.
}

gill, Lepomis macrochirus, black bullhead, Ictalurus melas, black crappie, Pomoxis nigromaculatus, green sunfish, Lepomis cyanellus, and carp, Cyprinus carpio, were scarce to common in all lakes during the study period.

\section{METHODS}

Areas of vegetated and nonvegetated lake shoreline were randomly sampled with a modified $30 \times 30 \mathrm{~cm}$ surber bottom sampler and a $30 \mathrm{~cm}$ wide push-net during the peak of the pike spawning season. Samples were collected from depths of $20-45 \mathrm{~cm}$. The incubation period for the eggs in natural lakes varied from 8 to 12 days depending on water temperature. An Eckman dredge was tried but discarded because of its inherent failure to close with vegetation in the grab. Duplicate sweeps at the same site were made to check efficiency. Approximately $94 \%$ of all eggs deposited on a site were collected during the first $30 \times 30 \mathrm{~cm}$ sweep. Collected samples were washed through a U. S. standard sieve (No. 30) screen and the eggs counted under magnification.

\section{RESULTS AND DISCUSSION}

Greatest egg densities were found on flooded native prairie grasses, i.e., sand bluestem, $A n$ dropogon hallii, little bluestem, $A$. scoparius, porcupine grass, Stipa spartea, sideoats grama, Bouteloua curtipendula, and sandlove grass, Eragrostis trichodes (Table 1). In the absence of such flooded grasses, similar numbers of eggs were found on mowed hay and broken hay bales left on the ground and inundated during the March-April pike spawning period. Both flooded grasses and mowed hay were especially attractive for pike in Big 
Alkali and Mother Lakes, two large, slightly alkaline lakes where about $95 \%$ of the submergent aquatic vegetation consisted of scattered stands of sago pondweed, Potamogeton pectinatus. Although both lakes have extensive emergent vegetation, i.e., Scirpus sp., Phragmites sp., Typha sp., and Sagittaria sp., such plants were seldom utilized as spawning sites.

Watts Lake, a 102-ha, slightly alkaline lake, was extensively searched for pike eggs in 1960 and 1961. About 78\% of the eggs collected were found in beds of bushy pondweed, Najas flexilis, which comprised only about $18 \%$ of the submergent plant association in the lake. The dominant submergent species were milfoil, Myriophyllum spicatum and coontail, Ceratophyllum demersum which occurred in dense stands throughout the lake. The Myriophyllum-Ceratophyllum group in Watts Lake was one of the least productive egg collection sites (Table 1).

The two bays in Watts Lake where $N$. flexlis was the dominant plant produced an average of eight eggs per $30 \mathrm{~cm}^{2}$, whereas the extensive shoreline growth of Scirpus sp., Phragmites sp., and open water stands of MyriophyllumCeratophyllum contributed only about one egg per $30 \mathrm{~cm}^{2}$. The sandy-silt bottom region, without vegetative cover, averaged less than one egg per $30 \mathrm{~cm}^{2}$ and clearly represented the least desirable substrate for the deposit of pike eggs.

Frame and gill nets were set in Watts Lake amidst various habitats during the spawning season. Nets set in two bays with stands of $N$. flexlis caught 765 adult pike compared to a total catch of 56 in all other habitats. During 1960-61, Schoenecker ${ }^{2}$ estimated the spawning pike population for Watts Lake at 1,391-3,912 fish. Apparently a high proportion of the population were attracted to stands of Najas during the spawning period.

Of the 16 vegetated sites examined in Pelican, a 405-ha, slightly alkaline lake, about $90 \%$ of the pike eggs were found deposited over inundated grasses and shallow water growth of Elodea sp. and Potamogeton pectinatus. Extensive growth of $M$. spicatum and $C$. dem-

\footnotetext{
${ }^{2}$ Schoenecker, William. 1962. Unpublished report Nebraska Game and Parks Commission.
}

ersum contained less than $5 \%$ of the total eggs collected in Pelican Lake during 1963-64. The remainder of the eggs were recovered from scattered stands of curleyleaf pondweed, Potamogeton perfoliatus richardsonii.

Peckham, ${ }^{3}$ following a pike mark and recovery study on Pelican Lake during 1966-70, estimated that the spawning pike population varied between 12,800 to 28,300 fish.

Spawning pike used Chara sp. almost exclusively in Shell Lake, a 79-ha, slightly alkaline lake in Cherry County. Of the eight sites examined among Chara sp., $M$. spicatum, $C$. demersum and $P$. perfoliatus richardsonii growth, Chara sp. contained $92 \%$ of the eggs collected with no eggs found in samples among $C$. demersum and $M$. spicatum.

Water quality, spring water levels and temperatures, and the species of submergent aquatic vegetation present within individual lakes all influence pike spawning success in the sandhill region. Aside from adverse low water temperatures, which may delay or prohibit spawning, the direct effects of alkalinity limiting biological production in both temporal and permanent sandhill lakes is paramount (McCarraher, 1971). Excessive alkalinity, > $900 \mathrm{mg} / \mathrm{l}$, appears to restrict distribution of some species of aquatic vegetation, i.e., $M$. spicatum, C. demersum, Utricularia sp., and Anacharis canadense. The elimination of the latter two species from alkaline waters is perhaps significant since we have found them to be important spawning sites for pike in sandhill lakes. $P$. pectinatus and Chara sp. are often the only submergent plant substrate available in lakes where alkalinity varies between $900-1,200 \mathrm{mg} / 1$. Such alkaline lakes often have closed drainage basins with little spring flooding of adjacent meadow grasses. Within these lakes the $P$. pectinatus-Chara sp. association provides pike spawning habitat of good quality (Table 1). However, the pike populations are usually eliminated from alkaline lakes when the total alkalinity exceeds 1,000 $\mathrm{mg} / \mathrm{l}, \mathrm{CO}_{3}$ alkalinity $>200 \mathrm{mg} / 1$ and $\mathrm{pH}>$ 9.6 (McCarraher, 1962). Thus, alkalinity not only directly influences the survival and distribution of aquatic vegetation in the sandhill

\footnotetext{
${ }^{3}$ Peckham, Richard. 1970. Unpublished report Nebraska Game and Parks Commission.
} 
lakes, but also influences the growth, reproduction and survival of pike.

\section{ACKNOWLEDGMENT}

The authors express particular thanks to Richard Peckham, formerly fisheries manager at Bassett, Nebraska for his assistance in the collection of spawning site data at the Valentine State Fish Hatchery in 1968.

\section{LITERATURE CITED}

Carbine, W. F. 194l. Observations on the life history of the northern pike, Esox lucius, in Houghton Lake, Michigan. Trans. Amer. Fish. Soc. 71: 149-164.

Clark, C. F., and F. Steinbach. 1959. Observations on the age and growth of the northern pike, Esox lucius, in East Harbor, Ohio. Ohio J. Sci. 59(3) : 129-134.

Fabricius, E., and Kard-Jacob Gustafson. 1958. Some new observations on the spawning behavior of the pike, Esox lucius. Rep. Inst. Freshwater Res. Drottningholm 39: 23-54.

ForNeY, J. L. 1968. Production of young northern pike in a regulated marsh. N. Y. Fish Game J., $15(2)$ : I43-154.

Franklin, D. R., ANd L. L. Smith, Jr. 1963. Early life history of the northern pike, Esox lucius L., with special reference to the factors influencing the numerical strength of year classes. Trans. Amer. Fish. Soc. 92(2) : 91-110.

Frost, W. E., AND C. Kipling. 1967. A study of reproduction, early life, weight-length relationship and growth rate of pike, Esox lucius L., in Windermere. J. Anim. Ecol. 36 (3) : 651-693.

MCCARRAHER, D. B. 1971. The small playa lakes of Nebraska, their ecology, fisheries and biological potential. Playa Lake Symp. Trans., International Center for Arid and Semi-Arid Land Studies, Texas Tech. Univ., Lubbock, Texas.

- 1962. Northern pike, Esox lucius, in alkaline lakes of Nebraska. Trans. Amer. Fish. Soc. $91(3)$ : $326-329$.

D. B. MCCarRaher

RoBert E. THOMAS

Nebraska Game and Parks Commission

Hastings College

Hastings, Nebraska 68901

Nebraska Game and Parks Commission

Lincoln, Nebraska 68503 